Short Communication

\title{
Fatty Acid Composition and Antimicrobial Activity of Celtis australis L. Fruits
}

\author{
R. Badoni, D. K. Semwal ${ }^{*}$, and U. Rawat \\ Department of Chemistry, University of Garhwal, Srinagar-246174, Uttarakhand, India \\ Received 25 December 2009, accepted in revised form 23 March 2010
}

\begin{abstract}
Methyl esters of fatty acid obtained from Celtis australis fruits were subjected to GC-MS in order to determine the identity and concentration of its constituents. Methyl oleate (25.7\%), methyl palmitate $(22.2 \%)$, methyl tricosanoate $(13.3 \%)$, methyl lineolate $(7.8 \%)$, methyl dotriacentanoate $(2.6 \%)$ and methyl 14-acetylhydroxypalmitate $(2.1 \%)$ were the major constituents out of total characterized composition (95.455\%) of fatty acid. The ethanolic extract of fruits was used for evaluating its antimicrobial activity against Staphylococcus aureus, Pseudomonas auroginosa, Escherichia coli and Bacillus subtilis. The extract showed significant results against $P$. auroginos $a$ and $E$. coli. The antimicrobial activity and fatty acid analysis of $C$. australis of fatty acid fruits has been carried out for the first time.
\end{abstract}

Keywords: Celtis australis; Ulmaceae; methyl oleate; methyl tricosanoate; Pseudomonas auroginosa; Escherichia coli.

(C) 2010 JSR Publications. ISSN: 2070-0237 (Print); 2070-0245 (Online). All rights reserved.

DOI: $10.3329 /$ jsr.v2i2.4056 J. Sci. Res. 2 (2), 397-402 (2010)

\section{Introduction}

Celtis australis vern. Kharik belonging to family Ulmaceae is a deciduous tree distributed to montane and submontane Himalaya [1]. The paste obtained from the bark of $C$. australis is effective remedy for bone fracture and also applied on pimples, contusions, sprains and joint pains [2]. Previously, betulin-3,3'-di-O-methylellagic acid, gallic acid and quebrachilol were reported from the bark [3] whereas acacetin 7-O-glucoside, isovitexin and cytisoside were isolated from leaves of the plant [4]. Recently, we have isolated a novel sulphonated phenolic celtisanin from the fruits of this plant [5]. This is the first chemical report together with antimicrobial activity on fruits of this plant.

\footnotetext{
*Corresponding author: dr_dks.1983@yahoo.co.in
} 


\section{Material and methods}

\subsection{Plant material}

The ripe fruits of $C$. australis were collected from Bhatwara, District Tehri Garhwal Uttarakhand. The plant was identified by Taxonomical Laboratory, Department of Botany, H.N.B. Garhwal University Srinagar. A voucher specimen (GUH-17595) of the plant has been deposited in Departmental Herbarium for future record.

\subsection{Extraction and isolation}

Shade dried fruits of $C$. australis (4 kg) were extracted exhaustively (3 times) with $95 \%$ ethanol $(5 \mathrm{~L})$ at $50^{\circ} \mathrm{C}(15 \mathrm{~h})$. The extraction mixture was filtered and concentrated under reduced pressure to yield a black residue $\left(200 \mathrm{~g}, 50^{\circ} \mathrm{C}\right)$. This residue was further extracted with ethyl acetate using soxhlet apparatus to obtained ethyl acetate soluble fraction $(50 \mathrm{~g})$. This fraction was concentrated and applied on the top of silica gel packed column. The elution was first started with hexane and the polarity was increased by $\mathrm{CHCl}_{3}$. The fractions were collected each $50 \mathrm{ml}$ and combined on the basis of TLC analysis. The elution of hexane-chloroform (60:40) afforded viscous liquid $(3 \mathrm{ml})$ as a separate layer with $\mathrm{CHCl}_{3}$. The viscous liquid (characteristic properties of fatty oils) was separated out by separating funnel.

\subsection{FT-IR analysis}

The separated viscous liquid was subjected to FT-IR (Perkin-Elmer Spectrum RX I FT-IR spectrometer, $\mathrm{KBr}$ disc, $1 \mathrm{mg}$ ) analysis for determination of its fatty acid nature. The IR spectrum displayed the strong bands at 2960 and $2870 \mathrm{~cm}^{-1}$ (C-H stretching of methylene groups), $1735 \mathrm{~cm}^{-1}$ (carbonyl groups), 1470 (C-H bending) and $1183 \mathrm{~cm}^{-1}$ (C-O stretching).

\subsection{Esterification of fatty acid}

The methyl derivatives of fatty oil constituents were prepared by following the method described by Wang and co-workers [6]. The fatty oil $(0.3 \mathrm{~g})$ was added to $0.5 \mathrm{~cm}^{3}$ of potassium hydroxide-methanol solution $\left(0.5 \mathrm{~mol} \mathrm{dm}{ }^{-3}\right)$ and heated for $30 \mathrm{~min}$ at $60^{\circ} \mathrm{C}$. Then it was added to $1.0 \mathrm{~cm}^{3}$ boron trifluoride - methanol solution (1:2) and again heated for $30 \mathrm{~min}$ at $60^{\circ} \mathrm{C}$. To it petroleum ether and saturated sodium chloride solution $1 \mathrm{~cm}^{3}$ each were added. Finally, this mixture was centrifuged (REMI-R-8C, $10000 \mathrm{rpm}$ capacity) for $10 \mathrm{~min}$ at $3000 \mathrm{rpm}$ and the supernatant fluid was subjected to GC/MS analysis. 


\subsection{GC-MS analysis}

The analysis of fatty acid was performed with GC Perkin-Elmer-Clarus-500 plus MS Perkin-Elmer-Clarus-500 (Column: Perkin-Elmer HP 5-MS $=60 \mathrm{~m} \times 250 \mu \mathrm{m}$; oven: initial temp. $50{ }^{\circ} \mathrm{C}$ for $5 \mathrm{~min}$, ramp $3{ }^{\circ} \mathrm{C} / \mathrm{min}$ to $220{ }^{\circ} \mathrm{C}$; inj $=270{ }^{\circ} \mathrm{C}$; volume $=1 \mu \mathrm{l}$; split ratio $=100: 1$; carrier gas $=\mathrm{He}$; solvent delay $=5 \mathrm{~min}$; transfer temp $=250^{\circ} \mathrm{C}$; source temp $=180^{\circ} \mathrm{C}$ ). The individual constituents showed by GC were identified by comparing their MS with standard compounds of Nist and Willey libraries using deuterated n-alkane $\left(\mathrm{C}_{5}-\mathrm{C}_{18}\right)$ as internal standards. The relative concentrations of each constituent of fatty acid shown by gas chromatogram (Fig. 1) have been summarized in Table. 1.

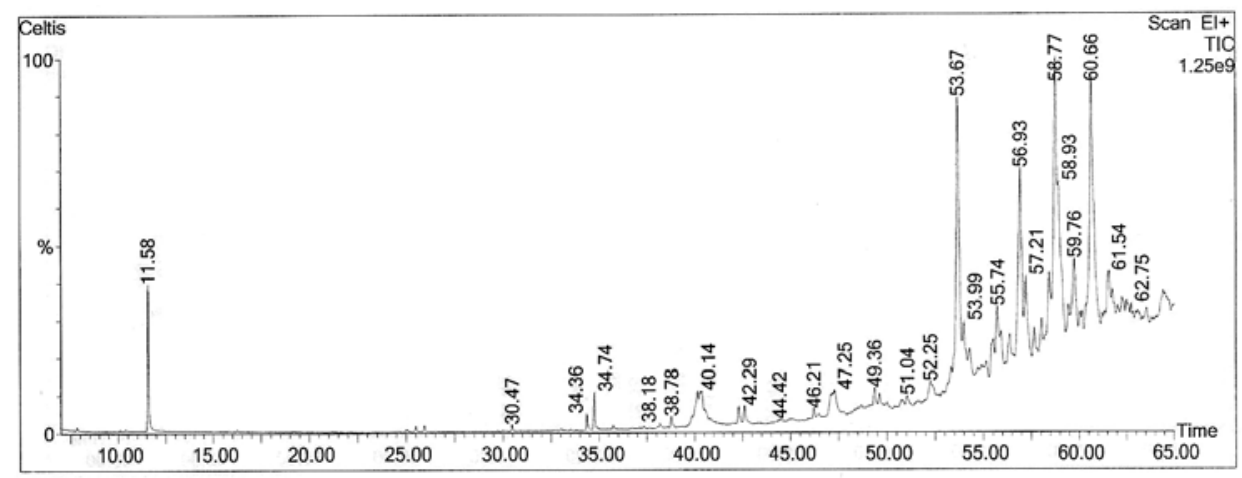

Fig. 1. Gas chromatogram of esterified fatty acid.

Table 1. The area percentages of chemical constituents of fatty oil.

\begin{tabular}{cll}
\hline Sl. no. & Constituents & Area $\%$ \\
\hline 1 & Octadecanoate & 2.730 \\
2 & Methyl 13-methyltetradecanoate & 1.454 \\
3 & Methyl palmitate & 22.235 \\
4 & Methyl 2,4-dimethyl heneicosanoate & 2.232 \\
5 & Methyl 1-tetradecanoate & 1.148 \\
6 & Methyl 1-dotriacontanoate & 1.124 \\
7 & Methyl 14-acetylhydroxypalmitate & 2.120 \\
8 & Methyl octadecanoate & 1.305 \\
9 & Methyl hexadecanoate & 2.141 \\
10 & Methyl linoleate & 7.798 \\
11 & 1,2-Epoxy-1-venylcyclododecane & 2.914 \\
12 & Methyl dotriacentanoate & 2.557 \\
13 & Methyl oleate & 25.744 \\
14 & Methyl tetradecanoate & 2.918 \\
15 & Methyl tricosanoate & 13.305 \\
16 & 2-Methylstearoate & 1.800 \\
17 & Teratriacontane & 1.930 \\
& Total & 95.455 \\
\hline
\end{tabular}




\subsection{Antimicrobial evaluation}

Antimicrobial activity with different concentrations of the extract (reconstituted with dimethyl sulfoxide) was evaluated by cup plate assay method. The minimum inhibitory concentration (MIC) was determined by serial dilution method against Staphylococcus aureus, Pseudomonas auroginosa, Escherichia coli and Bacillus subtilis.

\subsection{Antimicrobial susceptibility testing}

The experimentation was done in aseptic area under laminar air-flow cabinet. The agar diffusion method was adopted for the study [7]. Broth cultures of the test isolates $(0.1 \mathrm{ml})$ containing $3.0 \times 10 \mathrm{CFU} / \mathrm{ml}$ of organism was introduced into a sterile petri dish and $15 \mathrm{ml}$ of molten nutrient agar were added. The content was thoroughly mixed and then allowed to solidify. The extract was dissolved in DMSO and different concentrations were made. Erythromycin $(1 \mathrm{mg} / \mathrm{ml})$ and ampicillin $(1 \mathrm{mg} / \mathrm{ml})$ were used as standard for antibacterial activity. Holes were bored in the plate, using a standard sterile cork borer of $8 \mathrm{~mm}$ diameters and $100 \mu \mathrm{l}$ volume of the plant extract was transferred into the wells with the aid of micropipette. The experiment was carried out in triplicate. The plate was incubated at $37{ }^{\circ} \mathrm{C} / 24 \mathrm{~h}$ [8]. At the end of incubation, zone of inhibition was measured in the plate (Table 2).

\subsection{Determination of minimum inhibitory concentration (MIC)}

MIC of the extract was determined by tube dilution method (turbimetric method). The microbial cultures were grown in nutrient broth for $24 \mathrm{~h}$ before being used. The cultures were diluted in broth at a density adjusted to a $0.5 \mathrm{McF}$ arland turbidity standard $\left[1-2 \times 10^{8}\right.$ CFUs/ml]. The bacterial suspensions were diluted 1:10 in broth and $100 \mu$ of it were used for the study. $2 \mathrm{ml}$ of the sterilized nutrient broth was introduced in each of the 5 test tubes. The extracts were serially diluted to give a concentration of $250,125,62.5,31.2$ and $15.6 \mu \mathrm{g} / \mathrm{ml}$. In all the test tubes $0.1 \mathrm{ml}$ of suspension of bacteria in saline was added and incubated at $37{ }^{\circ} \mathrm{C} / 24 \mathrm{~h}$ post-incubation the plates were observed for turbidity (Table 2).

\section{Results and Discussion}

In IR spectrum, the bands observed in the region of 3050 to $2860 \mathrm{~cm}^{-1}$ corresponded to the asymmetric and symmetric $\mathrm{C}-\mathrm{H}$ stretching of methyl and methylene groups were corroborated to fatty acids [9]. The extracted fatty acid of $C$. australis fruits was methylesterified and analyzed by GC/MS. The major components of esterified fatty acid were methyl oleate $(25.74 \%)$, methyl palmitate $(22.24)$, methyl tricosanoate $(13.31 \%)$, methyl linoleate $(7.80 \%)$, methyl 14-acetylhydroxypalmitate $(2.12 \%)$ and methyl 
dotriacentanoate $(2.56 \%)$. The area percentages of chemical constituents are given in Table 1.

The analysis of fatty acid from $C$. australis by GC/MS showed that it contains various bioactive constituents including methyl oleate, methyl tricosanoate, methyl pentachlorostearate, and methyl linoleate in major concentration. Methyl linoleate is essential for maintenance of growth and shown to be potent cycloxygenase-2 (COX-2) catalyzed prostaglandin biosynthesis inhibitors [10]. Methyl palmitate inhibits lipopolysaccharide-stimulated phagocytic activity of rat peritoneal macrophages [11]. Methyl oleate applied to the skin of ST/a mice promoted the induction of malignant skin tumors and had weak activity as a complete carcinogen to the skin. Methyl oleate was also shown to have some activity in promoting the induction of malignant lymphomas [12]. Methyl palmitate and methyl oleate exhibited characterisitic kairomonal probing behavior of $P$. biannulipe toward the lure [13]. Since, the fatty acid of $C$. australis fruits contains numerous bioactive compounds, therefore, the fatty acid can be further used to evaluate the various biological activities.

The results of antimicrobial activity have been summarized in Table 2. The extract was found active against Bacillus subtilis and Pseudomonas auroginosa with minimum inhibitory concentration of 250 and $125 \mu \mathrm{g} / \mathrm{ml}$, respectively. The preliminary screening revealed the presence of terpenoids and phenolics in the extract [3-5]. These constituents might be responsible for antimicrobial activity.

Table 2. IZD ( $\mathrm{mm})$ and MIC $(\mu \mathrm{g} / \mathrm{ml})$ of the extract tested for antimicrobial activity.

\begin{tabular}{llllllll}
\hline & \multicolumn{3}{l}{ Zone of Inhibition $(\mathrm{mm}) \pm \mathrm{S} . \mathrm{D}$} & & \multicolumn{3}{c}{$\begin{array}{l}\text { Minimum inhibitory } \\
\text { concentration }(\mu \mathrm{g} / \mathrm{ml})\end{array}$} \\
\cline { 2 - 8 } $\begin{array}{l}\text { Micro Organism } \\
(0.1 \mathrm{ml})\end{array}$ & $\mathrm{CA}$ & $\mathrm{E}$ & $\mathrm{A}$ & $\mathrm{DMSO}$ & $\mathrm{CA}$ & $\mathrm{E}$ & $\mathrm{A}$ \\
& $100 \mathrm{mg} / \mathrm{ml}$ & $1 \mathrm{mg} / \mathrm{ml}$ & $1 \mathrm{mg} / \mathrm{ml}$ & solvent & - & 1 & 16.8 \\
\hline S. aureus & $18.2 \pm 1.0$ & $31.2 \pm 0.25$ & $28.2 \pm 0.34$ & $15 \pm 0.86$ & - & 1 & 16.8 \\
$\begin{array}{l}\text { B. subtilis } \\
\text { P. auroginosa }\end{array}$ & $21.3 \pm 0.58$ & $32.1 \pm 0.98$ & $26.4 \pm 0.48$ & $16 \pm 0.22$ & 250 & 1 & 16.8 \\
E. coli & $19.6 \pm 0.87$ & $27.5 \pm 1.14$ & $20.6 \pm 0.52$ & $15 \pm 1.12$ & 125 & - & 250 \\
\hline
\end{tabular}

$\mathrm{CA}=$ Celtis australis $; \mathrm{E}=$ Erythromycin; $\mathrm{A}=$ Ampicillin .

Crude extracts from the plants are generally contains both active and non-active constituents. The minimum inhibitory concentration of less than $500 \mu \mathrm{g} / \mathrm{ml}$ for pure compounds may be suggestive of a good antimicrobial activity. Usually, the extract having large inhibition zone diameter with low minimum inhibitory concentration can be recognized as more potent drug than that of small inhibition zone diameter and high minimum inhibitory concentration [7]. The low minimum inhibitory concentration (125 and $250 \mu \mathrm{g} / \mathrm{ml}$ ) shown by extract against tested organisms was corroborated to a good 
antimicrobial agent and could be an alternate to the antibiotics in the treatment of infections caused by these microorganisms since most of them have developed resistance against the known antibiotics [14]. Now a days, the herbal drugs gain popularity due to their highly potent activity and low adverse effects. Therefore this drug may perhaps be the suitable therapeutics option of an antimicrobial agent.

\section{Acknowledgements}

The authors pay their sincere thanks to UGC New Delhi, India [Grant No. 33282/2007(SR)], for financial assistance and to Dr. B. N. College of Pharmacy, Mumbai, India for allowing to carry out the antimicrobial work.

\section{References}

1. B. D. Naithani, Flora of Chamoli, Vol. 2 (Botanical Survey of India, Department of Environment, New Delhi, 1985) p. 575.

2. R. D. Gaur, Flora of District Garhwal North West Himalaya (Trans Media, Media House, Srinagar, 1999) p. 84.

3. V. M. S. Chari, S. Neelakanta, and T. R. Seshadri, Indian J. Chem. 6, 231 (1968).

4. R. Spitaler, S. Gurschler, E. Ellmerer, B. Schubert, M. Sgarboss, and C. Zidorn, Biochem. System Ecol. 37, 120 (2009). doi:10.1016/j.bse.2008.11.020

5. R. Badoni, D.K. Semwal, U. Rawat, and G. J. P. Singh, Nat. Prod. Res. 2010 (In press).

6. X. Wang, J. Yao, and Z. Yu, Chem. Pap. 59, 240 (2005).

7. D. K. Semwal, U. Rawat, A. Bamola, and R. Semwal, J. Sci. Res. 1 (3), 662 (2009). doi:10.3329/jsr.v1i3.2423

8. O. A. Oyedeji and A. J. Afolayan, Pharma. Biol. 43, 249 (2005). doi:10.1080/13880200590928843

9. R. Karoui, E. Dufour, L. Pillonel, E. Schaller, D. Picque, T. Cattenoz, and J. O. Bosset, Int. Dairy J. 15, 287 (2005). doi:10.1016/j.idairyj.2004.07.005

10. T. Ringbom, U. Huss, A. Stenholm, S. Flock, P. Skatteboel, P. Perera, and L. Bohlin, J. Nat. Prod. 64, 745 (2001). doi:10.1021/np000620d

11. S. Sarkar, M. F. Khan, B. S. Kaphalia, G. A. S. Ansari, J. Biochem. Mol. Toxicol. 20, 302 (2006). doi:10.1002/jbt.20150

12. E. Arffmann and K. Glavind, Acta Pathol. Microbiol. Scand. Sect. A. Pathol. 82, 127 (1974).

13. S. Tebayashi, T. Kawahara, C. Kim, A. Nishi, K. Takahashi, A. Miyanoshita, and M. Horiike, Z. Naturforsch. 58c, 295 (2003).

14. P. Singleton, Bacteria in Biology, Biotechnology and Medicine, 4th Edition (John Wiley and Sons Ltd, New York, 1999). 